\title{
Coursework for Promoting Teaching and Learning
}

\author{
G.W.T.C. Kandamby ${ }^{1}$ \\ ${ }^{1}$ Institute of Technology, University of Moratuwa, Sri Lanka \\ Correspondence: Senior Lecturer, Institute of Technology, University of Moratuwa, Diyagama, Homagama, Sri \\ Lanka
}

Received: November 1, 2017

Accepted: December 7, 2017

Online Published: December 11, 2017

doi:10.5430/ijhe.v6n6p129

URL: https://doi.org/10.5430/ijhe.v6n6p129

\begin{abstract}
Teaching is to be amalgamated with learning environment where students attend work with interest. Coursework was designed and conducted for Quantity Surveying module from 2014 as a study and found that it has supported for promoting teaching and learning. It was revealed that encouragement made only for attendance is not sufficient to obtain high performance. With developed coursework in 2016, students have obtained high marks for yearend paper reaching to grades A and B by $35 \%$ and $46 \%$ respectively. In addition, more than $82 \%$ of students have expressed that the method conducted was at good level. High impact obtained in 2015 and 2016 may be due to the experience gathered by the teacher in implementing this method continuously and therefore this coursework benefited not only to the students but also to the teachers as both parties are able to achieve their objectives with high performances.
\end{abstract}

Keywords: Teaching, Learning, Coursework, Attendance, Performance

\section{Introduction}

Civil Engineering Technology is one of the programs under National Diploma in Technology conducted in Sri Lanka where selection of students is based on advanced level results of physical science stream and aptitude test. These students are capable of understanding civil engineering principles as they have followed mathematics and physics in their advanced level studies. Different teaching methods are practiced in higher educational program according to the syllabus of the module for gaining knowledge, skills and attitudes of the students. Lecturing is the most common teaching method for large groups of students and tutorial is usually conducted for some modules for small groups. Quantity surveying (Q.S.) is one of the modules in civil engineering technology program where 80 students are in one batch following 2 hours lecture per week for 30 weeks based on verbal presentation using multimedia. Since major part of this module consists of calculations which are illustrated by working examples on whiteboard, discussing with the students and allowing adequate time for them to note down required information. In addition to lectures, this module consists of 3 hours tutorial classes per week for ten weeks. Tutorial classes are included in teaching plan simultaneously with lectures allowing students to apply the knowledge gained from the lectures to the given coursework. It is based on preparation of Bill of Quantities (B.O.Q.) document for building construction project which is carried out individually getting assistance from the tutor to complete the work within the period. Coursework pass grade and yearend written paper is the assessment criteria of this module where three hour paper is to be answered which contains compulsory two questions of B.O.Q.

The knowledge required for building construction for this module was acquired by the students in the previous year and working out quantities of building works were covered during the first part of the lecture series of this module. It was noted that students' participation for the tutorial classes was very poor and anyhow they have submitted the coursework at the end of the year in 2012. Marks obtained for the end examination of this module were not up to the expected standard though the students have submitted the completed coursework. In 2013, students were guided to attend the tutorial classes and allow them to carry out the work with the support of the tutor. It was noted that no significant gain in yearend paper marks in 2013, though students have shown good attendance. Therefore it was decided to change the way of conducting coursework especially considering students' active participation on these activities for learning. This new method was introduced in 2014 with the start of the program as a study and continued till it was completed at the end of the year.

This study will be a support for the teacher as it is decided to introduce semester system including continuous assignment to this program from 2018. Experience gathered in handling such type of coursework along with good 
learning environment will benefit the teacher for designing and implementing a better system to this program in near future.

\section{Objectives}

Main objectives of this study are to determine the effect of the coursework conducted in the classroom with respect to students;

1. Participation for tutorial classes.

2. Attention for learning.

3. Involvement of carrying out a given work.

4. Performance at the paper in end examination.

\section{Methodology}

\subsection{Preparation of Coursework}

Aim of this coursework is to give knowledge for students to prepare detailed Bill of Quantities (B.O.Q) document with several bills for construction of a building project according to the given drawing. Coursework was designed by assigning simple tasks under several main tasks allowing students to carry out the work during the allotted time. Whole coursework consisted of expected area of learning with sufficient tasks which were arranged in order with the flow of lecture series. Simple building construction project was considered for this exercise by giving some details with coursework and others were given while carrying out the work. Taking off quantities for substructure, super structure, roof work, openings and finishes of a building were given as sub tasks of main task 1. Once this sub task was completed, students were able to undertake remaining tasks of this coursework. One requirement of this coursework is to submit the papers at the end of the day to the tutor to mark and give the feedback of the students' performance which was very useful for continuation of this process with less errors and mistakes. Students were expected to undertake the tasks with acquired knowledge gained during the lectures, maintain good relationship with the teacher and or the tutor to discuss their problems and complete the total coursework within ten tutorial classes.

\subsection{Implementation of Coursework}

Tutorial classes were conducted for separate two groups of 40 students providing good learning environment with the support of a tutor. Lecturer in charge of the subject (teacher) and the tutor attend the work in classroom level to assist students and get their involvement effectively for this learning exercise. Printed coursework and the relevant building drawing were issued to each student in the first day of the lecture by explaining its importance and made awareness of students prior to commence the work. It was an additional learning activity to the students and given adequate time for them to understand the subject and attend the work. Since the group of students was small, tutor assists students individually and manages the class to complete the work within the given period. They were encouraged by clarifying the information and discussing difficulties raised by the students. Each student should attend the work individually and submit the papers at the end of the day. It was a challenging work as no additional time was allowed for submission. Therefore good progress of attending the work was to be maintained. Students had the chance for studying at home and come ready with required information though it was open book exercise. Completion of each task is necessary to complete the final task of the coursework. Therefore it supported to keep the students continuous with the exercise and build up their knowledge gradually for the final outcome. Papers were marked and submitted to the students in the following day by giving their performance and discussing the feedback in order to motivate them for remaining works. Observation was made closely, while they were carrying out the work. The whole content of the coursework was completed within given ten tutorial days by attending the tasks continuously.

\section{Literature Review}

\subsection{Teaching and Learning}

Teaching and learning are going together. Teaching is to deliver information in the appropriate flow to enable students to collect, work with them to gain knowledge and skill which resulting in learning. The process of carrying out these activities has shown to be effective in getting students to learn. Teacher concerns the transmitting information of particular lesson to the students and students acquire the knowledge under the set learning outcomes. Achieving learning outcomes is the main objectives of the module which makes personal change or benefits as a results of learning. Teachers can support students to process information by helping them to organize new information, link it to their existing knowledge and use memory aids to retrieve information (Eady \& Lockyer, 2013). 
Preparation, execution and evaluation are three main components of total teaching process (Theresa, 2015). Teaching in absence of learning is just talking (Doyle, 2004). Effective teaching skills consist of high level of student engagement based on good classroom and time management skills (Jordan, Schwartz, \& McGhie-Richmond, 2009). Creating a situation and shaping it for appropriate learning is what successful teacher has learned to do effectively (Braskamp \& Ory, 1994). There are different methods of teaching. Most of the students have rated lecture and group discussion are the best way of teaching (Sajjad, 2006). Strength of the lecture is presenting factual materials in direct, logical manner, which is stimulates thinking to open discussion and is useful for large groups (Davis, 1993; McCarthy, 1992). Bloom was convinced that one to one tutorial instruction is the gold standard for education which would not be affordable for mass public education. Well-designed instructions would be effective for majority of students for whom it was intended to learn (William, 2011). Learning is the information-processing perspective, which considers learning as a change in knowledge in the stored memory (Eady \& Lockyer, 2013). It is not purely a mental activity for an academic subject, or purely a physical activity for the practical subjects. Most areas of learning have both mental and physical aspects, in different proportions (Gipps \& James, 1996). Some students have different attitudes towards learning. There has been an increasing tendency to seek to understand methods that are intended to guide the learning towards the goal that takes place during the learning process (William, 2011).

Monitoring students' learning can be performed engaging in one-to-one contacts with students about their work, assigning, collecting, correcting work and recording scores and identify gaps in their knowledge (Kathleen, 1988). In other hand, test is the primary motivation to study. The functions of test are to motivate and help students to learn what the instructor wants them to learn and enable instructor to use the extent to which they have succeeded in doing so (Felder, 1988). Motivation plays a major role in students' academic work and in their achievement (Peklaj \& Levpuscek, 2006). Motivation is a multidimensional construct. Researchers in the field of motivation (Wiegfield \& Eccles, 2000) agree that a student engaging in any learning situation has to answer three fundamental questions: 'Can I do this activity?', 'Do I want to do this activity and why?', and 'What do I need to do to succeed?' The next important aspect of the level of engagement in an activity is task value. Eccles et al. (1983) defined subjective task values as incentives for doing different tasks. Subjective task values have been found to be positively related to student achievement (Peklaj \& Levpuscek, 2006) Students can be motivated to engage in an activity when they believe that working on the given task will result in desired outcomes such as rewards, good grade or avoidance of punishment (Peklaj \& Levpuscek, 2006).

\subsection{Coursework}

Origin of coursework is course plus work. Any course in higher education usually comprises of several work activities in addition to its lectures aiming for better learning in order to acquire knowledge, skill and attitude with the completion of the course. According to the dictionary, coursework is a written or oral work completed by a student within given time frame. It can be considered as an additional teaching activity in the module which provides a good learning path for students to follow in the classroom. They get opportunity individually to use the acquired knowledge for practical applications and complete the work within the given time. Coursework can be considered as a classroom activity which is one of the options to obtain the feedback of the teaching as it responds directly to the concerned party about better learning and more effective teaching. It needs to be conducted at several instances during the cause of the delivering process so that time is available for the teacher to make any adjustment for better way of learning (Angelo \& Cross, 1993). Since the tutorial classes are usually with small numbers of students, teacher-student contact is easily maintained while doing the coursework. Students were assisted to carry out the calculation and motivate them to learn through the given work. Good relationship between teachers and students are important to motivate students and develop their academic achievement (Pennings et al., 2014). The dialog between students and teacher should be thoughtful reflective, focused to evoke and explore understanding and conducted so that all students have an opportunity to think and to express their ideas (Black \& William, 1998).

Learning through activities in classroom help to obtain knowledge through active participation, attend the learning with interest, and manage the given time to learn and answer. The collection of frequent feedback on students' learning, and the design of modest classroom experiments, teachers can learn much about how students learn and, how students respond to particular teaching approaches (Angelo \& Cross, 1993). When attitudes toward testing are studied, students who are tested frequently and given feedback are found to have positive attitudes toward tests. They are generally found to regard tests as facilitating learning and studying, and as providing effective feedback (Kathleen, 1988). According to Bloom, one to one tutoring is effective and tutor is able to identify errors in the student's work immediately (William, 2011). Students' attention and the extent of knowledge gained could be found while monitoring the performance through marks obtained for the given tasks. Practice of monitoring student learning is an essential component of high-quality education. 


\subsection{Assessments}

Assessment includes a wide range of methods for evaluating pupil performance and attainment including formal testing and examinations, practical and oral assessment, classroom based assessment carried out by teachers (Gipps, 1994). Assessment developed historically for the purposes of selection and certification particularly, selection for further educational opportunities beyond the minimum state provision and for employment (Torrance, 1995). Assessment experts have recognized and argued in favor of assessment as an essential component to learning. It promotes learning and is a change from being a 'measure of learning' to becoming a 'support to learning' (Buhagiar, 2007).). Assessment does not stand outside teaching and learning, but stands in dynamic interaction with it (Gipps, 1994). Assessment is more than just a technical activity. It is a human activity that influences and affects many people (Airasian, 2000). The appropriate assessment model inside the classroom is one that is designed to support the teaching and learning of important skills and concepts at both basic and higher levels (Buhagiar, 2007). Assessment for learning has come to refer to any assessment for which the first priority is to serve the purpose of promoting students' learning (Black, Harrison, Lee, Marshall, \& William, 2003). Assessing the performance of students is considered to be the most important thing a teacher can do for their students and it can have a profound effect on their learning (Trotter, 2006).It is so important because it is created, administered, and analyzed by teachers themselves on questions of teaching and learning that are important to them, the likelihood that instructors will apply the results of the assessment to their own teaching is greatly enhances (Angelo \& Cross, 1993). Performance assessment requires students to carry out an activity or produce a product that demonstrate both knowledge and skill (Airasian, 2000). It reveals that any type of assessment will be supported for students' learning.

Assessment is a process that includes four basic components such as measuring improvement over time, motivating students to study, evaluating the teaching methods and ranking the students' capabilities in relation to the whole group evaluation (Taghi, 2009). Purpose of classroom assessment is to improve the quality of student learning, not to provide evidence for evaluating or grading students. Assessment for learning has disseminated four interventions: questioning, feedback for marking, peer-and-self assessment and formative use of summative tests (Taras, 2010). Test questions helped students to understand the ways in which examiners pose questions and expect them to be answered. It also increased the students' sense of control over the assessment process and confidence in tackling exams (Hodgson \& Pyle, 2010). Evaluation of the students' performance is highly concerned with qualitative judgments that are used to improve students' knowledge and learning. Assessment and evaluation also give teachers useful information about how to improve their teaching methods. Through using appropriate classroom assessment strategies and techniques, teachers can increase their students' motivation and show them how well they have learned (Taghi, 2009). An effective classroom assessment and evaluation calls on teachers to become agents of change in their classrooms actively using the results of assessment to modify and improve the learning environments they create (Taghi, 2009). The overall message of summative tests should be, and should seem to be, a positive part of the learning process (Black et al 2003). In addition, summative assessment is responding to accountability demand of some organizational higher authority. It involves judging performance for a decision or record (Ewell, 2005). Summative assessments are tools to help evaluate the effectiveness of programs, school improvement goals, alignment of curriculum, or student placement in specific programs.

\subsection{Feedback}

Feedback is conceptualized as information provided by an agent (e.g. teacher, peer, book, self, experience, parent) regarding aspects of one's performance or understanding (Hattie \& Timperley, 2007). There are ways of obtaining feedbacks for both teaching and learning in higher education. Teacher can obtain the feedbacks for teaching from the respective group of students and students can get feedbacks for their learning from the teachers by participating academic activities which are designed by the teachers for the need of the module before sitting the final tests. The evidence collected from these feedbacks is very useful to study and understand the areas which are to be improved or modified to make successful teaching and learning. It will be beneficial to both parties to correct and make the processes effective and efficient. Feedback needs to provide information specifically relating to the task or process of learning that fills a gap between what is understood and what is aimed to be understood (Sadler, 1989). Considerable research evidence are available to show that effective feedback leads to learning gain and has produced significant benefits in learning and achievement of knowledge and skills of education (Nicol \& Macfarlane-Deck, 2006). Butler (1988) has demonstrated that feedback comments alone increased students' subsequent interest in learning when compared with two other controlled situations, one where only marks were given and the other where students were given feedback and marks. Grading student performance has less effect than feedback comments because feedback focuses on the difficulties faced by the student in the task and it take effort to improve them (Butler, 1987). Feedback is seen as a primary component in formative assessment and one of the factors that have the strongest influence on 
learning (Black \& William, 1998). To improve learning, students need to receive appropriate and focus feedback early to know how to assess their own learning (Angelo \& Cross, 1993). Teacher can also assist by clarifying goals, enhancing commitment or increased effort to reaching them through feedback (Hattie \& Timperley, 2007). In higher education, most students have little opportunity to use directly the feedback for closing the performance gap especially in the case of planned assignments as the students should move to the next assessment task soon after feedback is received (Nicol \& Macfarlane-Deck, 2006). This paper (Nicol \& Macfarlane-Deck, 2006) has discussed some principles of good feedback practice in detail and mentioned that feedback on work in progress and increased opportunities for resubmission would be much effective rather than giving feedback at the end of the work. Feedback is among the most critical influences on student learning. If it is directed at the right level, it can assist students to comprehend, engage or develop to process the information intended to be learned (Hattie \& Timperley, 2007).

\section{Data Collection}

Number of students and their attendance in the tutorial classes from 2012 to 2017 were recorded for this study and indicated them in Table 1.

\subsection{Attendance}

Table 1 . Summary of students' attendance in tutorial classes

\begin{tabular}{|c|c|c|c|c|c|c|c|c|c|c|c|}
\hline \multicolumn{2}{|c|}{2012} & \multicolumn{2}{|c|}{2013} & \multicolumn{2}{|c|}{2014} & \multicolumn{2}{|c|}{2015} & \multicolumn{2}{|c|}{2016} & \multicolumn{2}{|c|}{2017} \\
\hline$\%$ & $\begin{array}{c}\text { No. } \\
\text { Students }\end{array}$ & $\%$ & $\begin{array}{c}\text { No. } \\
\text { Students }\end{array}$ & $\%$ & $\begin{array}{c}\text { No. } \\
\text { Students }\end{array}$ & $\%$ & $\begin{array}{c}\text { No. } \\
\text { Students }\end{array}$ & $\%$ & $\begin{array}{c}\text { No. } \\
\text { Students }\end{array}$ & $\%$ & $\begin{array}{c}\text { No. } \\
\text { Students }\end{array}$ \\
\hline 100 & 8 & 100 & 13 & 100 & 29 & 100 & 30 & 100 & 23 & 100 & 29 \\
\hline 88 & 1 & 91 & 22 & 88 & 16 & 88 & 24 & 90 & 14 & 88 & 16 \\
\hline 86 & 4 & 82 & 23 & 86 & 7 & 78 & 22 & 86 & 14 & 86 & 7 \\
\hline 83 & 19 & 73 & 10 & 80 & 9 & 67 & 4 & 80 & 9 & 80 & 9 \\
\hline 75 & 3 & 64 & 5 & 75 & 9 & 50 & 1 & 70 & 12 & 75 & 9 \\
\hline 71 & 3 & 55 & 3 & 71 & 3 & & & 60 & 7 & 71 & 3 \\
\hline 67 & 12 & 45 & 2 & 63 & 2 & & & 43 & 2 & 63 & 2 \\
\hline 63 & 9 & 36 & 1 & 63 & 2 & & & & & 60 & 1 \\
\hline 57 & 6 & 27 & 2 & 60 & 1 & & & & & 57 & 1 \\
\hline 50 & 8 & & & 57 & 1 & & & & & 50 & 3 \\
\hline 43 & 1 & & & 50 & 1 & & & & & & \\
\hline 38 & 1 & & & & & & & & & & \\
\hline 29 & 2 & & & & & & & & & & \\
\hline 14 & 1 & & & & & & & & & & \\
\hline 13 & 1 & & & & & & & & & & \\
\hline Total & 79 & & 81 & & 80 & & 81 & & 81 & & 80 \\
\hline
\end{tabular}

\subsection{Performance for Yearend Examination}

Quantity Surveying marks obtained by the students for yearend examinations for 2013 to 2016 were collected and shown in Table 2. Examination for 2017 is not yet held. Marks for the grading A is $\geq 70$, B is between 69 and 55, C is between 54 and 40, D is between 39 and $30, \mathrm{E}$ is between 29 and $20 \mathrm{~F}$ is $<19$.

Table 2. Students' yearend paper marks

\begin{tabular}{lcccccc}
\hline \multicolumn{7}{c}{ Students' performance - Grading \% } \\
Year & A & B & C & D & E & F \\
\hline 2013 & 4 & 31 & 47 & 12 & 4 & 2 \\
2014 & 8 & 27 & 43 & 15 & 6 & 1 \\
2015 & 23 & 47 & 26 & 4 & 0 & 0 \\
2016 & 35 & 46 & 15 & 4 & 0 & 0 \\
\hline
\end{tabular}




\subsection{Students' Feedback}

Students' comments on this exercise were collected in 2015 and 2017 as feedbacks by producing the questionnaire to study under the method of conducting the coursework and learning process for acquiring knowledge. Data collected was presented in Table 3.

Table 3. Summary of students' feedback

\begin{tabular}{lllll}
\hline Students' Comments & 2015 & & 2017 & \\
& Good & Satisfactory & Good & Satisfactory \\
\hline Method followed for conducting coursework & $84 \%$ & $12 \%$ & $82 \%$ & $15 \%$ \\
Learning process for acquiring knowledge & $70 \%$ & $18 \%$ & $72 \%$ & $21 \%$ \\
\hline
\end{tabular}

\section{Analysis and Results}

\subsection{Attendance and Performance of Yearend Paper}

Collected data for attendance was analyzed as percentages in ten ranges indicated in Table 4. No attendance was reported below $10 \%$.

Table 4. Students Attendance from 2012 to 2017

\begin{tabular}{|c|c|c|c|c|c|c|c|c|c|c|}
\hline \multirow[b]{2}{*}{ Attendance - } & \multicolumn{10}{|c|}{ Number of students - Cumulative } \\
\hline & $>10$ & $>20$ & $>30$ & $>40$ & $>50$ & $>60$ & $>70$ & $>80$ & $>90$ & 100 \\
\hline 2012 & 79 & 77 & 75 & 74 & 73 & 59 & 38 & 32 & 8 & 8 \\
\hline 2013 & 81 & 81 & 79 & 78 & 76 & 73 & 68 & 58 & 35 & 13 \\
\hline 2014 & 80 & 80 & 80 & 80 & 80 & 77 & 75 & 64 & 25 & 25 \\
\hline 2015 & 81 & 81 & 81 & 81 & 81 & 80 & 76 & 54 & 30 & 30 \\
\hline 2016 & 81 & 81 & 81 & 81 & 79 & 79 & 72 & 60 & 37 & 23 \\
\hline$\stackrel{\Xi}{\circlearrowright} 2017$ & 80 & 80 & 80 & 80 & 80 & 76 & 73 & 61 & 29 & 29 \\
\hline
\end{tabular}

According to the By- Law of this program, more than $70 \%$ of attendance for seven subjects including tutorial classes (out of nine subjects) is required to obtain eligibility of sitting examinations. This was $48 \%$ of students in 2012. Therefore, students were motivated for attendance of tutorial classes of Q.S. without changing the way of conducting coursework exercise in 2013 and found that it reached to 84\%. This was rapid increase. When observing the marks obtained by the students for yearend written paper in 2013, it was found that there was no such improvement of students' performance with respect to the increased attendance. Therefore it is revealed that doing tutorials without providing active work environment in the classroom for learning (by assessing for the given exercise and giving continuous feedback) the students are unable to engage learning as expected.

Table 5. Students' attendance with respect to By-Law

\begin{tabular}{lll}
\hline & \multicolumn{2}{l}{ Attendance } \\
Year & $<70 \%$ & $\geq 70 \%$ \\
\hline 2012 & 52 & 48 \\
2013 & 16 & 84 \\
2014 & 9 & 91 \\
2015 & 6 & 94 \\
2016 & 11 & 89 \\
2017 & 9 & 91
\end{tabular}

With the beginning of tutorial classes with the designed coursework in 2014, increase of attendance up to $91 \%$ may be due to the fact that students have shown interest on attending this new learning exercise by carrying out given tasks and observing their feedbacks. Performance gained for yearend paper on grade A increased from $4 \%$ to $8 \%$. Good attendance was recorded during this exercise period from 2014 to 2017 (89\% to $94 \%$ of attendance). Analyzed data in Table 4 is graphically presented in Figure 1 which indicates that the distributions of attendance of six groups 
of students were similar in shapes. These graphs have gradually moved to higher level of attendance by indicating a positive change in the process due to the results of coursework exercise.

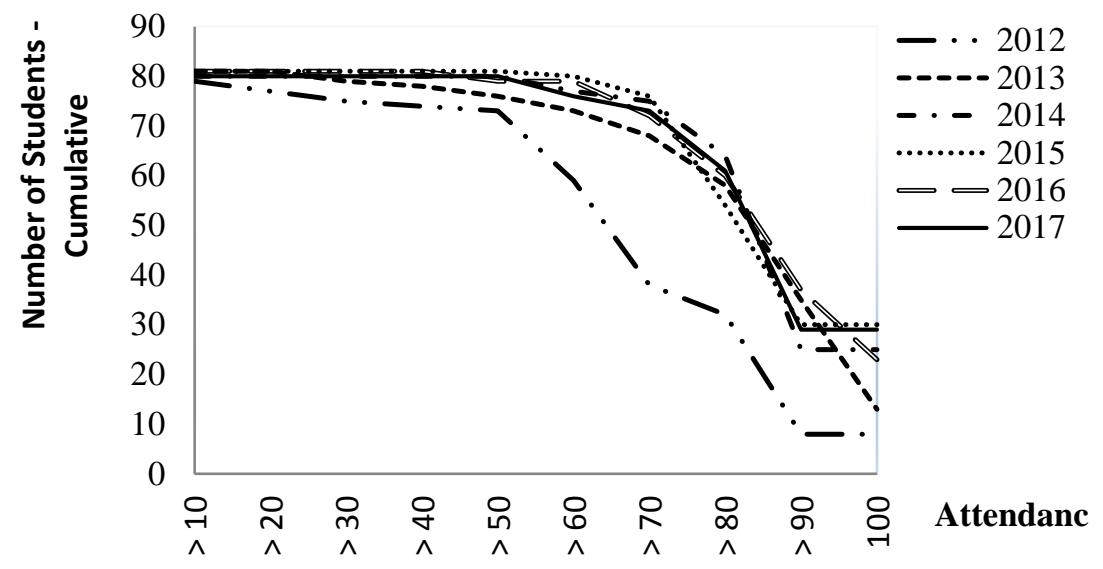

Figure 1. Students' Attendance from 2012 to 2017

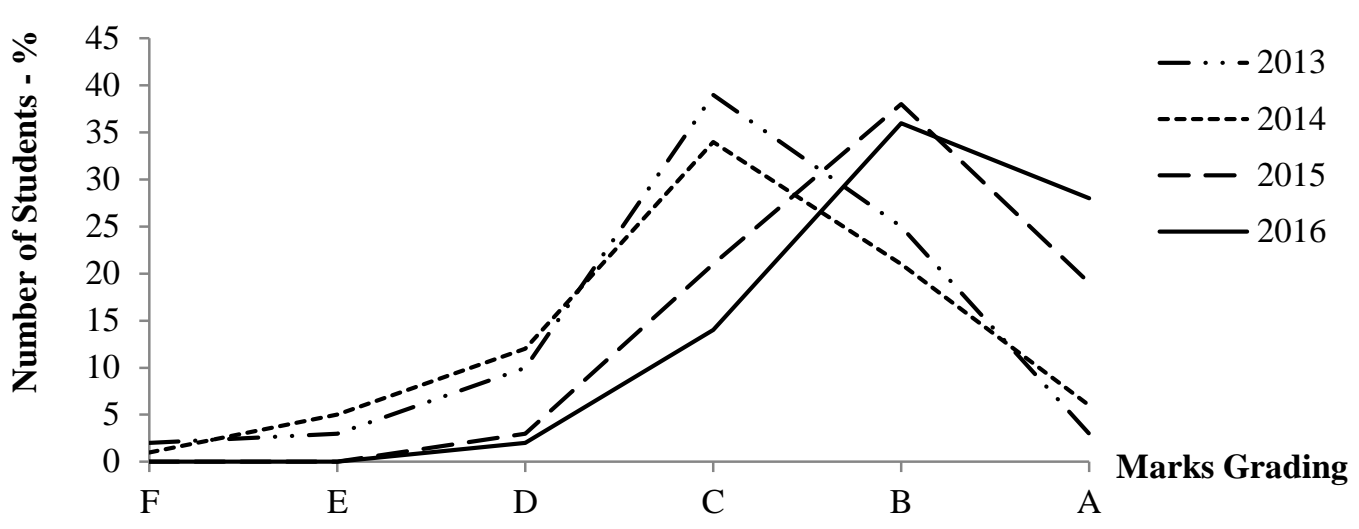

Figure 2. Students' Marks for written Paper in yearend Examination (From 2013 to 2016)

With the continuous application of this system from 2014, marks obtained for the yearend written paper increased in 2015 and 2016while showing good attendance. Final performance of 2015 and 2016 for obtaining grade A was 23\% and $35 \%$ (from $8 \%$ ) and Grade B was $46 \%$ and $47 \%$ (from $27 \%$ ) respectively. Simultaneously, failing marks under grade $\mathrm{D}, \mathrm{E}$ and $\mathrm{F}$ decreased from $15 \%$ to $4 \%, 6 \%$ to $0 \%$ and $2 \%$ to $0 \%$ with good attendance as indicated in Figure 1 .

Figure 2 clearly presents the yearend paper marks for four groups of students from 2013 to 2016 which skewed to right side indicating that results moved to high level of marks keeping all graphs were in similar shapes. Therefore, remarkable change should be in the process and it was the outcome of the coursework exercise. In addition, gradual increase in marks may be due to the experience of handling this new method gathered by the teacher from its application in 2014. Yearend examination is not yet held for 2017. Peaks are now at Grade B level which was at Grade C in year 2013 and 2014.

Results of this study indicate remarkable achievement on students learning. Therefore, learning process needs systematic way of teaching amalgamated with coursework exercise which provides continuous assessments in classroom level and feedback for encouraging students to attend the work by active participation.

\subsection{Students' Feedback}

Feedback collected from questionnaire survey in 2015 and 2017 was analyzed as percentages under following two area of the study.

a) Method of conducting the coursework.

b) Knowledge gained from this coursework exercise. 

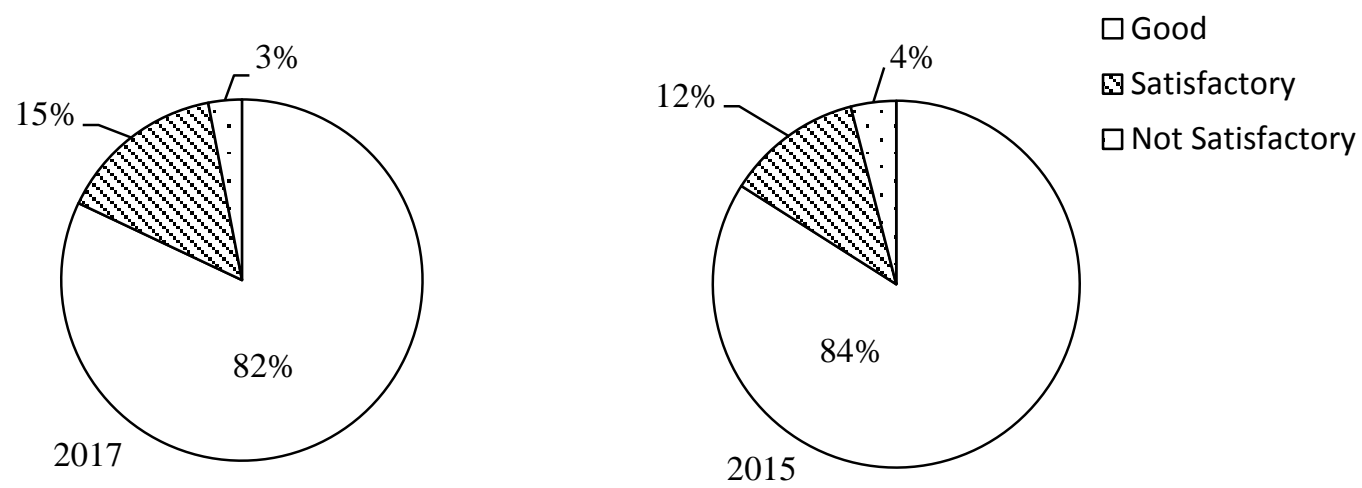

Figure 3. Students' Feedback for method of conducting coursework

In 2015 and 2017, more than $82 \%$ of students have mentioned that method of conducting this exercise was good. Only $3 \%$ and $4 \%$ of students has informed that the process was not satisfactory. Sometimes they did not perform these exercises well. Data was collected through questionnaire anonymously, students' individual performances were not considered.

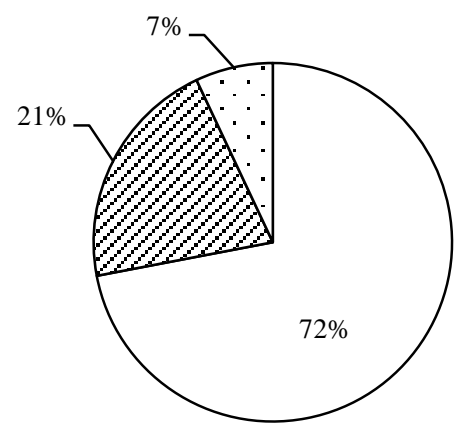

2017

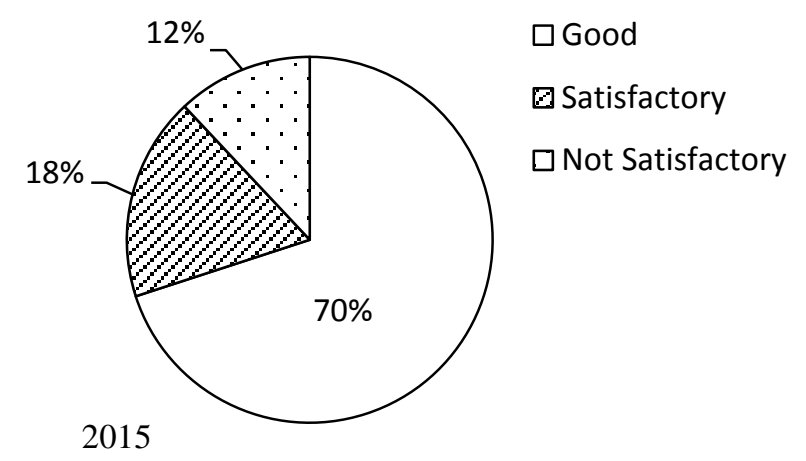

Figure 4. Students' Feedback for knowledge gained from coursework

More than $70 \%$ of students have mentioned that this process supported for them to gain knowledge and it was a good learning method. When compared with the yearend marks in 2015, there was a rapid increase in marks may be because they learnt well under this exercise.

Students have given good feedback for this exercise by rating average $82 \%$ and $71 \%$ for (a) and (b) respectively. When the feedback is totally considered, it revealed that more than $88 \%$ of students have rated as this process is at satisfactory level.

Students' feedbacks, their yearend paper marks, attendance and observations noted during the tutorial classes have shown good results focused on teaching and learning of Q.S. module because of the method adopted from 2014 using this coursework exercise.

\section{Conclusions}

From the literature review, it is found that good teaching is not only delivering the factual material direct to the students for enhancing their knowledge but also providing a good learning environment where students play their role with active involvement in learning. Investigation of students' performance through classroom assessment and giving feedback continuously will also support for promoting students' learning. This phenomenon was applied in the coursework exercised under Q.S. module as a study and found that the application is possible and really supported for promoting teaching and learning. Further it is revealed that this coursework exercise helped to improve students' attendance, build good relationship with the teacher, encourage students for active participation and give required knowledge to the students specially achieve to high performance at end examination. It is revealed that 
improvement made on attendance ( $84 \%$ in 2013) is not sufficient to obtain high performance (grade A was $4 \%$ and grade B was $31 \%$ in 2013) as there was no such change in method of teaching and learning. With the developed coursework exercise specially focused on teaching and learning has shown high performance of grade A and B reached to $35 \%$ and $46 \%$ respectively while keeping attendance at $89 \%$ in 2016 . Therefore, students' engagement for classroom levels of exercises is necessary to improve their knowledge and skill.

In addition, students have expressed the positive attitude on the method adopted for them to learn under this exercise by rating $88 \%$ for satisfactory level and out of that $77 \%$ for commenting as it was a good level. Results of the study have shown that high impact on this exercise at latter years may be due to the experience gathered by the teacher by implementing it in 2014. This coursework exercise applied for teaching and learning process has benefited not only to the students but also to the teachers as both parties are able to achieve their objectives with high performances.

\section{References}

Airasian, P.W. (2000). Assessment in the classroom: A Concise Approach (2nd ed.). Boston: McGraw-Hill.

Angelo, T. A., \& Cross, K.P. (1993). Classroom assessment techniques, Handbook for College Teachers. (2nd ed.), Jossey-Bass, San Francisco.

Black, P., Harrison, C., Lee, C., Marshall, B., \& William, D. (2003). Formative and summative assessment: Can they serve learning together. Retrieved from http:/www.kcl.ac.uk//depsta/education/hpages/pblackpubs.html.

Black, P., \& William, D. (1998). Assessment and classroom learning. Assessment in Education: Principles, Policy \& Practice, 5(1), 7-75. https://doi.org/10.1080/0969595980050102

Bloom, B. S. (1984). The search for method of instruction as effective as one to one tutoring. Educational leadership, 41(8), 4-17.

Braskamp, L.A., \& Ory, J.C. (1994). Assessing faculty work: Enhancing individual and instructional performance, Jossey-Bass Inc. publishers, San Francisco.

Buhagiar, M.A. (2007). Classroom assessment within the alternative assessment paradigm: revisiting the territory. The Curriculum Journal, 18(1), 39-56. https://doi.org/10.1080/09585170701292174

Butler, R., (1988). Enhancing and undermining intrinsic motivation: the effects of task-involving and ego-involving evaluation on interest and involvement. British journal of Educational Psychology, 58, 1-4. https://doi.org/10.1111/j.2044-8279.1988.tb00874.x.

Davis, B.G. (1993). Tools for Teaching, Jossey-Bass Publishers, San Francisco.

Doyle, T., (2004). Evaluating Teachers' Effectiveness, Retrieved from ferris.edu/fctl/Teaching and Learning Tips/../EvalTeachEffec.htm.

Eady, M.J., \& Lockyer, L. (2013). Tools for learning: technology and teaching strategies. Learning to teach in the primary school, Queensland University of Technology, Australia, pp 71. http://ro.uow.edu.au/asdpapers/403

Eccles, J., Adler, T. F., Futterman, R., Goff, S. B., Kaczala, C. M., Meece, J., \& Midgley, C. (1983). Expectancies, values and academic behaviors. San Francisco.

Ewell, P. T. (2005). Assessment, accountability, and improvement: Revisiting the Tension, National Institute for learning outcomes assessment.

Felder, R.M. (1988). Learning and teaching styles in engineering education, Engr. Education, 78(7), 674-681.

Gipps, C.V. (1994). Beyond testing: towards a theory of educational assessment, The Falmer Press (A member of the Taylor \& Francis Group) London.

Gipps, C., \& James, M. (1996). Assessment matched to learning, Symposium of the BERA Assessment Policy Task Group, BERA Conference. Retrieved from http://www.leeds.ac.uk/educol/documents/000000085.htm.

Hattie, J., \& Timperley, H. (2007). The power of feedback. Review of Educational Research, 77-81. https://doi.org/10.3102/003465430298487

Hodgson, C., \& Pyle, K., A literature review of Assessment for Learning in science. National Foundation for Educational Research, 1.34.

Jordan, A., Schwartz, E., \& McGhie-Richmond, D. (2009). Preparing teachers for inclusive classrooms. Teaching and Teacher Educational, 25(4), 535-542. https://doi.org/10.1016/j.tate.2009.02.01

Kathleen, C. (1988). Monitoring students learning in the classroom. School improvement research series, Office of 
Educational Research and Improvement (OERI), Department of Education, U.S.

McCarthy, P. (1992). Common Teaching methods, Retrieved from http://honolulu.hawii.edu/internet/committees/FacDevCom/guidelk/teachtip/comteach.htm.

Nicol, D. J., \& Macfarlane - Dick, D. (2006). Formative assessment and self - regulated learning: a model and seven principles of good feedback practice. Studies in Higher Education, 31(2), 199-218. https://doi.org/10.1080/03075070600572090

Peklaj, C., \& Levpuscek, M.P. (2006). Students' motivation and academic success in relation to the quality of individual and collaborative work during a course in educational psychology. Annual ATEE conference, 147-161. Retrieved from www.pef.uni-lj.si/atee/978-961-6637-06-0/147-161.

Pennings, H.J.M., Tartwijk, J., Wubbels, T., Claessens, L.C.A., Want, A. C., \& Brekelmans, M. (2014). Real-time teacher-student interactions: A Dynamic systems approach. Teaching and Teacher Education 37, 183-193. https://doi.org/10.1016/j.tate.2013.07.016

Sadler, D. R. (1989). Formative assessment and the design of instructional system. Instructional Science, 18, 119-144. https://doi.org/10.1007/BF00117714

Sajjad, S. (2006). Effective Teaching methods at higher education level, University of Karachi, Pakistan. Retrieved from http://class.web.nthu.edu.tw/ezfiles/669/1669/img/1381/1

Taghi, J. (2009). The importance of classroom assessment and evaluation in educational system, Proceedings of the $2^{\text {nd }}$ International Conference of Teaching and Learning, INTI University College, Malaysia.

Taras, M. (2010). Assessment for learning: assessing the theory and evidence. Procedia Social and Behavioral Sciences 2, 3015-3022. https://doi.org/10.1016/j.sbspro.2010.03.457

Theresa, E. D. (2015). Different teaching methods: A panacea for effective curriculum implementation in classroom, International journal, secondary education, special issue, 3(6-1), 77-87. https://doi.org/10.11648/j.ijsedu.s.2015030601.13

Torrance, E. P. (1995). Insights about Creativity: Questioned, Rejected, Ridiculed, Ignored. Educational Psychology, Review, 7, 313-322. https://doi.org/10.1007/BF02213376.

Trotter, E. (2006). Student perceptions of continuous summative assessment. Assessment and evaluation in higher education, 31(5). https://doi.org/10.1080/02602930600679506

Wigfield, A. \& Eccles, J.S. (2000). Expectancy-Value Theory of Achievement Motivation. Contemporary Educational Psychology, 25, 68-81. https://doi.org/10.1006/ceps.1999.1015

William, D. (2011). What is assessment for learning? Studies in Educational Evaluation, 37, 3-14. https://doi.org/10.1016/j.stueduc.2011.03.001 